\title{
Business and Politics
}

Volume 11, Issue 3

2009

Article 2

Global ECONOMIC Governance: BeyOnd MANAGEMENT BY THE UNITED STATES AND THE EUROPEAN UNION?

\section{Reluctance to Lead: U.S. Trade Policy in Flux}

Vinod Aggarwal, UC Berkeley

Recommended Citation:

Aggarwal, Vinod (2009) "Reluctance to Lead: U.S. Trade Policy in Flux," Business and Politics: Vol. 11: Iss. 3, Article 2.

DOI: $10.2202 / 1469-3569.1257$ 


\title{
Reluctance to Lead: U.S. Trade Policy in Flux
}

\author{
Vinod Aggarwal
}

\begin{abstract}
The U.S. is no longer providing leadership in trade policy. In recent years, we have seen a sharp turn toward a rapid proliferation of bilateral preferential trade agreements, accords that are likely to undermine the World Trade Organization (WTO). By pursuing a strategy of 'competitive liberalization' both on a sectoral basis under the Bill Clinton administration, and then a policy of seeking bilateral arrangements under the George W. Bush administration, this article argues that American administrations have undermined the coalition for free trade in the United States. Consequently, protectionist industries including textiles, steel, and agriculture have made further liberalization more difficult and thus the prospects for promoting continued trade liberalization have grown dimmer.
\end{abstract}

KEYWORDS: U.S. trade policy, competitive liberalization, trade agreements, murky protectionism

Author Notes: Vinod K. Aggarwal is Professor of Political Science, Affiliated Professor of Business, and Director of the Berkeley APEC Study Center at the University of California at Berkeley. A previous version of this article was prepared for presentation at the 1st Transatlantic Economic Dialogue entitled: "A Declining Regime? America and Europe in the Multilateral Trading System," Center for Transatlantic Relations, SAIS, sponsored by the BMW Stiftung Herbert Quandt, Washington D.C., March 4-5, 2008. I greatly appreciate Heribert Dieter's role in organizing the conference and special issue. Because I am the Editor-in-Chief of Business and Politics, I am particularly grateful to Associate Editor John Ravenhill for taking responsibility for securing anonymous reviews of all of the papers including this one. In revising this paper, I have benefited from an Abe Fellowship of the Japan Foundation for 2008-2009, comments from referees, and research assistance from Peter Volberding. 
Aggarwal: Reluctance to Lead: U.S. Trade Policy in Flux

\section{INTRODUCTION}

Trade policy in the United States is moribund. The president has no trade authority from Congress to negotiate trade agreements, protectionist sentiment has risen dramatically, and prospects for continued trade liberalization are grimparticularly in the context of the global financial crisis of 2008-2009. When it comes to trade, in the last 15 years the U.S. has moved from leader to follower. When U.S. trade negotiators are asked why they pursued bilateral preferential trade agreements (PTAs), ${ }^{1}$ their answer is: "Everyone else is doing it." Indeed this is the same refrain one hears from the EU, and almost all other countries engaged in the negotiation of PTAs. Yet while small countries might be forgiven for this rather unconvincing excuse for what they clearly recognize as detrimental behavior for the global trading system, as key powers in the trading system, both the U.S. and the EU bear considerably more responsibility for promoting an open trading order. In the case of large powers - including India, China, and other rising countries - this argument simply rings hollow, reflecting a lack of strong leadership rather than any politically sophisticated strategy.

The irony of the decline of trade leadership is that at least in the eyes of many, the U.S. has been engaged in an "innovative" strategy of "competitive liberalization." 2 Indeed the Business Roundtable advocated the pursuit of PTAs to keep up with the Europeans, and the title of their brief is telling: "The Case for U.S. Leadership: The United States is Falling Behind." 3 Yet as I argue, this policy has had the unintended effect of undermining the coalition for free trade in the United States. At the same time, I do not ascribe any sinister motives to government, business leaders, or policy analyst who support this policy-only a lack of understanding of the political economy of trade policy. Criticism of PTAs is hardly new: Jagdish Bhagwati, a leading trade economist, has long pointed to the disruptive nature of such accords for some time, including in his most recent book. ${ }^{4}$ Yet he primarily concern has been on the disruptive global effect of such accords - not on the underlying erosion of a free trade coalition in the United States.

To preview my argument, the logic of my claim runs as follows. With respect to the current U.S. political economy of trade, the U.S. strategy of competitive liberalization - by which it has pursued piecemeal liberalization through open sectoral agreements such as the Information Technology Agreement

\footnotetext{
${ }^{1}$ Although negotiators prefer to refer to their bilateral accords as "free trade agreements" they are more appropriately termed "preferential trade agreements" as Jagdish Bhagwati 2008 has aptly noted.

${ }^{2}$ This approach can also be termed "piecemeal liberalization."

${ }^{3}$ Business Roundtable 2001.

${ }^{4}$ Bhagwati 2008.
} 
(ITA), bilateral PTAs, and calls for transregional accords such as the Free Trade Area of the Asia Pacific (FTAAP) - has fractured the domestic coalition for free trade. By giving specific industries what they wanted, this policy has left protectionists in agriculture, steel, textiles, and others in control of the trade policy agenda. The most recent manifestation of the strength of domestic protectionist interests has being the rise of unilateral protectionist measures in the U.S. in the context of the financial crisis - or what some have labeled "murky protectionism."

Those who bemoan the lack of progress in the World Trade Organization's (WTO) Doha Development Round (DDR) fail to recognize the obvious unfortunate causality connecting the insidious nature of piecemeal protectionism. In my view, rather than enhancing prospects for significant progress in the DDR, it the very pursuit of such partial accords that has been a key contributor to the DDR's problems. Both in their statements and actions, lack of progress at the end of every effort to conclude the DDR has been met by renewed efforts to conclude PTAs - creating an alternative that allows leaders to avoid the hard political tradeoffs across issues that are necessary to secure a meaningful DDR. The ultimate irony is that although under some circumstances one could make an argument for countering other countries' PTAs by negotiating one's own, ${ }^{6}$ the current lack of TPA means that the U.S. no longer has the ability to negotiate such agreements - even if it wished to do so.

The remainder of the paper is organized as follows. Section I characterizes the many different types of trade agreements that might be negotiated, both in theory and in practice. Section II then considers the political problems that have been created through the pursuit of competitive liberalization. Specifically, based on the framework developed in Section I, it shows how U.S. policy has moved away from its previous strong commitment to multilateral multi-product trade liberalization as the central approach to bilateral and minilateral broad and sector specific accords - often with security rather than economic motivations. Section III then examines the domestic political dynamics of current U.S. trade policy, focusing on the rise of "murky protectionism" in the United States and elsewhere. The paper concludes with some policy prescriptions.

\section{VARIETIES OF TRADE GOVERNANCE}

In the post-World War II period, states have utilized a host of measures to regulate trade flows. Yet in their examination of such accords, analysts have conflated different types of arrangements and used them synonymously. For

\footnotetext{
${ }^{5}$ Baldwin and Evenett 2009. As they note, many countries, not only the U.S., are pursuing such measures.

${ }^{6}$ For an example of a "domino approach" to PTAs, see Baldwin 1997.
} 
example, the term "regional agreement" has been used to refer to widely disparate accords such as APEC, the Asia Europe Meeting (ASEM), the North American Free Trade Agreement (NAFTA), interregional and transregional bilateral free trade agreements, and even sectoral agreements such as the ITA. ${ }^{7}$

This conceptual ambiguity and under-differentiation of the dependent variable makes it more difficult to develop causal arguments to account for specific outcomes. To more clearly specify different types of trade arrangements, I focus on several dimensions: the number of participants involved in an agreement, product coverage and/or issue coverage), geographical scope, marketopening or closing, and institutionalization. I define the number of participants in terms of unilateral, bilateral, minilateral, and multilateral participation in an agreement. I use the term bilateral to refer to two countries and minilateral to more than two. ${ }^{8}$ In terms of product coverage, the range is from narrow (a few products) to broad (multiproduct) in scope. Geographical scope differentiates between arrangements that are concentrated geographically and those that bind states across great distances. A fourth dimension addresses whether these measures have been either market opening (liberalizing) or market closing (protectionist). Fifth and finally, one can also look at the degree of institutionalization or strength of agreements. ${ }^{9}$ Table 1 summarizes a typology of trade agreements with illustrative examples based on these dimensions but omits discussion of the degree of institutionalization for presentation purposes.

Sectoral unilateralism in cell 1 focuses on market opening or closing measures, with the classic example being the British Corn Laws of 1815 and their subsequent removal in $1846 .^{10}$

Sectoral Bilateral Regionalism in cell 2 refers to agreements between a pair of countries that are geographically concentrated. The best example of this kind is the U.S.-Canada Automotive Products Trade Agreement of 1965. Prior to the 1988 Canada-U.S. Free Trade Agreement (CUSFTA), the Auto Agreement was the only major success in the long-standing effort to liberalize bilateral trade between the U.S. and Canada.

\footnotetext{
${ }^{7}$ See, for example, Mansfield and Milner 1999, p. 592, who recognize the problematic nature of the term "regionalism" but then proceed to use this term in their analysis.

${ }^{8}$ This usage differs from that of Yarbrough and Yarbrough 1992, which conflates third party enforcement with these terms so that "bilateral" for them can also mean three countries, a highly counterintuitive use. Keohane 1990 refers to an agreement among three or more states as multilateralism. Richardson 1987 is consistent with my usage.

${ }^{9}$ Of these, the dimension of geographical scope is the most controversial. It is worth noting that this category is quite subjective, since simple distance is hardly the only relevant factor in defining a "geographic region." Despite the interest that regionalism has attracted, the question of how to define a region remains highly contested. See the discussion by Mansfield and Milner 1999 and Katzenstein 1997, among others.

${ }^{10}$ See Schonhardt-Bailey 1996.
} 
Sectoral Bilateral Transregionalism in cell 3 refers to accords between two countries that are geographically dispersed. Examples of this sort of protectionist agreement include Voluntary Export Restraints (VERs) and potentially market-opening measures such as voluntary import expansions (VIEs), both of which have generally but not always crossed regions. ${ }^{11}$

Sectoral Minilateral Regionalism in cell 4 reflects agreements between three or more countries that are geographically close to each other. The best example is the European Coal and Steel Community (ECSC), created in 1951. From the start, the ECSC faced criticism for its inconsistency with Article 24 of

Table 1: Classifying Varieties of Trade Governance ${ }^{12}$

\begin{tabular}{|c|c|c|c|c|c|c|c|}
\hline & & \multicolumn{6}{|c|}{ NUMBER OF PARTICIPANTS } \\
\hline & & \multirow{2}{*}{ Unilateral } & \multicolumn{2}{|c|}{ Bilateral } & \multicolumn{2}{|c|}{ Minilateral } & \multirow{2}{*}{ Multilateral } \\
\hline & & & $\begin{array}{l}\text { Geographically } \\
\text { Concentrated }\end{array}$ & $\begin{array}{l}\text { Geographically } \\
\text { Dispersed }\end{array}$ & $\begin{array}{l}\text { Geographically } \\
\text { Concentrated }\end{array}$ & $\begin{array}{l}\text { Geographically } \\
\text { Dispersed }\end{array}$ & \\
\hline \multirow{2}{*}{ 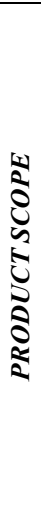 } & $\begin{array}{l}\text { Few } \\
\text { Products } \\
\text { (Sectoral) }\end{array}$ & $\begin{array}{l}(1) \\
\text { UK Corn } \\
\text { Laws } \\
(1815) \\
\text { UK Corn } \\
\text { Law } \\
\text { removal } \\
(1846)\end{array}$ & $\begin{array}{l}\text { (2) } \\
\text { U.S.-Canada } \\
\text { Auto } \\
\text { Agreement } \\
(1965)\end{array}$ & $\begin{array}{l}\text { (3) } \\
\text { U.S.-Japan } \\
\text { VERs and VIEs } \\
(1980 \mathrm{~s}-1990 \mathrm{~s})\end{array}$ & $\begin{array}{l}\text { (4) } \\
\text { ECSC (1951) }\end{array}$ & $\begin{array}{l}\text { (5) } \\
\text { EVSL (1997) }\end{array}$ & $\begin{array}{l}\text { (6) } \\
\text { LTA (1962) } \\
\text { \& MFA } \\
(1974) \\
\text { ITA (1997) } \\
\text { BTA (1998) } \\
\text { FSA (1999) }\end{array}$ \\
\hline & $\begin{array}{l}\text { Many } \\
\text { Products }\end{array}$ & $\begin{array}{l}(7) \\
\text { UK (1860s) } \\
\text { Smoot } \\
\text { Hawley } \\
(1930)\end{array}$ & $\begin{array}{l}(8) \\
\text { Canada-U.S. } \\
\text { FTA (1989) } \\
\text { Japan-South } \\
\text { Korean FTA } \\
\text { (under } \\
\text { negotiation) }\end{array}$ & $\begin{array}{l}\text { (9) } \\
\text { U.S.-Israel FTA } \\
(1985) \\
\text { U.S.-Singapore } \\
\text { FTA (2004) } \\
\text { Japan-Mexico } \\
\text { FTA (2004) }\end{array}$ & $\begin{array}{l}\text { (10) } \\
\text { EC/EU } \\
(1958 / 1992) \\
\text { ASEAN (1967) } \\
\text { Mercosur } \\
(1991) \\
\text { NAFTA (1993) }\end{array}$ & $\begin{array}{l}(11) \\
\text { APEC (1989) } \\
\text { EU-Mercosur } \\
\text { (under } \\
\text { negotiation) }\end{array}$ & $\begin{array}{l}(12) \\
\text { GATT } \\
\text { /WTO } \\
(1947 / 1995)\end{array}$ \\
\hline
\end{tabular}

the General Agreement on Tariffs and Trade (GATT), which calls for liberalization on a multiproduct basis, rather than only for a few products. Although challenged as being inconsistent with the GATT by Czechoslovakia, the ECSC members managed to obtain a GATT waiver of obligation. ${ }^{13}$

Sectoral Minilateral Transregionalism in Cell 5 provides an example of geographically dispersed sectoral transregionalism. One example is the case of the Early Voluntary Sectoral Liberalization (EVSL) under the auspices of APEC. In Vancouver in 1997, ministers agreed to consider nine sectors as a package for fast track liberalization, but this approach garnered little political support. In the

${ }^{11}$ See Aggarwal, Keohane, and Yoffie 1987 on VERs; see Bhagwati 1987 on VIEs.

${ }^{12}$ Adapted from Aggarwal 2001.

${ }^{13}$ Curzon 1966, 266-268. 
end, the package was sent to the WTO rather than being considered for liberalization at the APEC level.

Sectoral Multilateralism in Cell 6 include market-opening measures such as the ITA, the Basic Telecom Agreement (BTA), and the Financial Service Agreement (FSA) as well as market-closing measures such as the Long Term Arrangement on Cotton Textiles (LTA) and the Multfiber Arrangement (MFA), with the latter expanding managed trade beyond cotton products.

Multiproduct Unilateralism as in Cell 7 includes the most significant example of opening that took place in Britain in the late nineteenth-century. Contemporary examples include unilateral liberalization measures taken by Australia, New Zealand, Chile, Hong Kong, and Singapore. The most important market-closing measures in took place in the U.S. with the Smoot-Hawley Tariff of 1930 that set a cycle of trade protectionism in motion and aggravated the depression.

Multiproduct Bilateral Regionalism of both a regional and transregional actor scope has rapidly proliferated over the last few years. Cell 8 refers to bilateral trade agreements covering multiple products between a pair of adjacent countries, such as the CUSFTA of 1988 and Japan-South Korea preferential trade agreement (PTA) which has been negotiated in fits and starts - unsuccessfully to this point.

Multiproduct Bilateral Transregionalism, Cell 9, includes cases of geographically dispersed bilateral agreements covering multiple products. Examples include PTAs between the United States and Israel (1985), Mexico and Israel (2000), the United States and Jordan (2001), Japan and Singapore (2001), South Korea and Chile (2002), the United States and Singapore (2004), Japan and Mexico (2004), and many current negotiations involving the EU, China, Japan, and others.

Multiproduct Minilateral Regionalism, as noted in Cell 10 focuses on geographically concentrated minilateral agreements, the classic example being the EU. For the past decades, these types of accords have attracted the most scholarly attention, commensurate with the rise of regional trading arrangements since the 1960s. It is worth noting that in referring to many accords as "regionalism," we should be aware that this term only makes analytical sense for cells 2, 4, 8, and 10 of my typology. And even in these cases, as we can see, the types of accords differ on many dimensions, thus indicating the conceptual ambiguity and underdifferentiation inherent in the existing literature on regionalism.

Multiproduct Minilateral Interregionalism is another important recent development in trade arrangements concerns links that span countries across continents, as noted in Cell 11. Many analysts lump their examination of "minilateral regional" accords such as NAFTA and the EU with those of "minilateral interregional" arrangements such as the EU's efforts to link up with 
Mercosur, although the causal factors behind minilateral interregionalism are often quite different from those driving minilateral regionalism. The term "interregionalism" can itself be broken down into more specific types, based on the prevalence of PTAs and/or customs unions as constitutive units within interregional agreements. In work with Edward Fogarty, I refer to an agreement as "purely interregional" if it formally links free trade areas or customs unions, as in the case of EU-Mercosur. ${ }^{14}$ If a customs union negotiates with countries in different regions, but not with a customs union or free trade agreement, we refer to this as "hybrid interregionalism" (e.g., the Lomé Agreement). Finally, if an accord links countries across two regions where neither of the two negotiates as a grouping, then we refer to this as "transregionalism" (e.g., APEC).

Multiproduct Multilateralism, Cell 12 refers to the case of global, multiproduct trading arrangements such as the GATT and its successor organization, the WTO. Though highly successful throughout the postwar period, multilateral trade forums at the global level have increasingly encountered difficulties in hammering out new terms of trade liberalization. This, in turn, has fueled interest in preferential arrangements at the sub-multilateral level.

\section{THE TRANSFORMATION OF U.S. TRADE POLICY}

What trends have we seen in U.S. trade policy strategy in the post-WWII period? As we shall see, the decisive shift in the types of trade arrangements from multiproduct multilateral negotiations to a variety of other forms came in the mid to late $1980 \mathrm{~s}$ in the midst of the Uruguay Round negotiations.

\section{Multiproduct Multilateralism: U.S. Trade Policy from the Post-World War II Period to the Early $1980 \mathrm{~s}^{15}$}

With a dominant military force, a large market, enormous productive capacity, and a strong currency and financial system, the U.S. was well positioned to assume global responsibility at the end of the Second World War. It acted as military leader of the Western alliance, served as the world's central banker, and provided the major impetus for international trade liberalization. As a result, the 1950s and 1960s were marked by unprecedented economic growth and development. In particular, the "nested" context of the international trading system within the overall security system gave the U.S. executive leverage to resist domestically oriented protectionist groups.

\footnotetext{
${ }^{14}$ Aggarwal and Fogarty 2004.

${ }^{15}$ This subsection draws on Aggarwal and Lin 2002, which focuses on the pitfalls of what we term "opportunistic liberalization" and where we characterize U.S. trade policy as being recently characterized as strategy without vision. See the excellent concise discussion of historical trends in U.S. trade policy in Bergsten 2002. The classic account remains Destler 2005.
} 
The president could resist both congressional and interest group pressures by raising the specter of the Soviet and Chinese communist threat to U.S. interests, thereby allowing it to advance Cold War concerns over narrow parochial interests and foster free trade. ${ }^{16}$

The proposed International Trade Organization (ITO) failed to be ratified in the U.S. A coalition of protectionists and free traders in the United States rejected the ITO approach as an excessive compromise, preventing this arrangement from securing Congressional approval and its death. ${ }^{17}$ With the ITO moribund, the U.S. promoted a temporary implementing treaty, the GATT, as the key institution to manage trade on a multilateral basis in 1948. Although technically an interim framework for regulating and liberalizing world trade, the GATT turned out to be highly successful at overseeing international trade in goods and progressively reducing trade barriers.

This period is often dubbed the "golden age" of trade liberalization, witnessing a dramatic reduction of border barriers. But while this golden age of globalism was marked by significant coherence, it is worth noting that the 1950s were already marred by exceptions to a multilateral multiproduct approach to negotiations. Indeed, sectoralism emerged in textiles and in oil trade as early as the mid-1950s, while temporary VERs in textiles and apparel evolved into the increasingly protectionist multilateral MFA over a period of 40 years. ${ }^{18}$

Yet however repugnant the development of sector-specific arrangements from a pure free trade standpoint, the for President Kennedy, textiles and apparel protection was simply the necessary price to pay for the broader objective of what came to be known as the Kennedy Round of GATT negotiations. Most crucially, despite deviating from the norms of the GATT in some respects, the Long Term Arrangement on Cotton Textiles and the MFA were carefully nested in the GATT, and indeed the implementation and enforcement structure were housed in Geneva.

In the context of the negotiation of GATT rounds, the U.S. executive continued to face protectionist pressure from specific industries and was repeatedly forced to accommodate them. Soon after the Kennedy Round was concluded, the steel industry managed to secure voluntary export restraints to limit steel imports from Japan and the EEC in 1969. ${ }^{19}$ These VERs were dropped in 1974, but since then various new accords to limit steel imports have repeatedly been imposed and dropped. In footwear, orderly marketing arrangements were

\footnotetext{
${ }^{16}$ See Aggarwal 1985 for a discussion of the nesting of economic issues with a security context.

${ }^{17}$ Diebold 1952.

${ }^{18}$ For a theoretical and empirical analysis of the creation and evolution of the textile regime, see Aggarwal 1985.

${ }^{19}$ See Aggarwal, Keohane, and Yoffie 1987, which models the factors that explain why different industries have been able to secure protection of varying length.
} 
negotiated with Taiwan and South Korea in 1977, but these were dropped in 1981 and have not been reimposed. Similarly, OMAs restricting televisions from Japan, Korea and Taiwan came into effect from 1977 to 1979, but were then dropped from 1980 to 1982. In autos, President Reagan negotiated a VER with the Japanese in 1981, but by 1985 , these had also been dropped.

The central issue to keep in mind when thinking about the implications of sector-specific arrangements is their purpose. For example, in the case of sectoral arrangements in textiles and apparel, President Kennedy removed opposition by industries that viewed themselves as losing from freer trade. By appeasing these potent opponents, Kennedy was able to strengthen the coalition for free trade. Similarly, other agreements as in televisions, footwear, and autos have come into being for similar reasons, but in the case of those industries, were relatively temporary and have not been reimposed. By contrast, as I argue below, competitive liberalization has had the opposite effect, instead weakening the profree trade coalition. Thus, we must be careful in assessing the pros and cons of sectoral initiatives.

Table 2 illustrates the various trade agreements of which the U.S. was a part during the period of the 1950s to the early 1980s. As noted, the dominant U.S. approach during this period was clearly a GATT-based multilateral multiproduct approach with occasional highly focused deviations. Aside from the sectoral protectionist arrangements, the only other accord of any significance was the U.S.-Canada auto agreement. This agreement, tied to the automobile coproduction arrangements across the border, received a formal GATT waiver of obligation.

But in the early 1980s, following the Tokyo Round, change in the traditional approach was clearly in the air. The U.S. began to fear that European interest was now focused on widening and deepening of its regional integration efforts. With respect to the GATT, the 1982 effort to start a new round proved to be a failure, as most countries criticized the U.S. for attempting to included services and other new issues on the agenda. With problems in the GATT, in 1984, following the failed 1982 GATT Ministerial meeting, the U.S. Trade and Tariff Act authorized the administration to actively negotiate bilateral free trade agreements. Soon thereafter, the U.S. negotiated the Caribbean Basis Initiative (1983) and the U.S.Israel free trade (1985) agreement, made overtures to ASEAN, and undertook sectoral discussions with Canada in 1984, which ended in failure. But the direction was now clear: the U.S. now was willing to shift its own strategy away from pure multilateralism. 
Aggarwal: Reluctance to Lead: U.S. Trade Policy in Flux

Table 2: U.S. Trade Policy: 1940s to early 1980s

\begin{tabular}{|c|c|c|c|c|c|c|c|}
\hline & \multicolumn{6}{|c|}{ NUMBER OF PARTICIPANTS } \\
\hline & & \multirow{2}{*}{$\begin{array}{l}\text { Unila- } \\
\text { teral }\end{array}$} & \multicolumn{2}{|c|}{ Bilateral } & \multicolumn{2}{|c|}{ Minilateral } & \multirow[b]{2}{*}{ Multilateral } \\
\hline & & & $\begin{array}{l}\text { Geographically } \\
\text { Concentrated }\end{array}$ & $\begin{array}{l}\text { Geographically } \\
\text { Dispersed }\end{array}$ & $\begin{array}{l}\text { Geographically } \\
\text { Concentrated }\end{array}$ & $\begin{array}{l}\text { Geographically } \\
\text { Dispersed }\end{array}$ & \\
\hline \multirow[t]{2}{*}{ 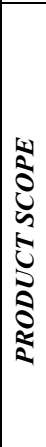 } & $\begin{array}{l}\text { Few } \\
\text { Products }\end{array}$ & (1) & $\begin{array}{l}\text { (2) } \\
\text { U.S.-Canada } \\
\text { Auto Agreement } \\
\text { (1965) }\end{array}$ & $\begin{array}{l}(3) \\
\text { U.S.-Japan, S. } \\
\text { Korea, Taiwan, } \\
\text { EC VERs } \\
(1960 \text { s-1980s) }\end{array}$ & (4) & $(5)$ & $\begin{array}{l}\text { (6) } \\
\text { Long Term } \\
\text { Agreement on } \\
\text { Cotton } \\
\text { Textiles } \\
(1962) \\
\\
\text { Multi-Fiber } \\
\text { Arrangement } \\
(1974)\end{array}$ \\
\hline & $\begin{array}{l}\text { Many } \\
\text { Products }\end{array}$ & (7) & (8) & (9) & (10) & (11) & $\begin{array}{l}(12) \\
\text { GATT (1947) }\end{array}$ \\
\hline
\end{tabular}

\section{Trade Policy after the mid-1980s: One Step Forward, Two Steps Backward ${ }^{20}$}

After considerable discussion, particularly over the inclusion of services, the GATT Uruguay Round got underway in 1986. Yet the U.S. kept up the pressure of using alternatives to the GATT to put pressure on other states in the ongoing negotiations. The signal was clear. Treasury Secretary James Baker warned in 1988:

If possible we hope that this...liberalization will occur in the Uruguay Round. If not, we might be willing to explore a market liberalizing club approach through minilateral arrangements or a series of bilateral agreements. While we associate a liberal trading system with multilateralism, bilateral or minilateral regimes may also help move the world toward a more open system. ${ }^{21}$

A high level of contentiousness continuously threatened the conclusion of the round. In part, this reflects the changing balance of power among more actors in the system, the dissolution of the liberal consensus and inclusion of diverse interests, and the unwillingness of the U.S. to continue to be the lender and market of last resort. The era of détente and the subsequent end of the Cold War further weakened the

${ }^{20}$ Adapted from Bergsten's 2002 “One Step Backward, Two Steps Forward” subtitle. For a discussion of the pros and cons of competitive liberalization, see also Feketekuty 1998; Aggarwal and Lin 2002; and Bergsten 1996.

${ }^{21}$ Toronto Star, 6 January 1988. 
security argument for continuing economic concessions in broad-based trade negotiations.

After considerable delay, the Uruguay Round came to a conclusion in 1993. But the U.S. was no longer solely committed to the multilateral route, as illustrated by its policy shift beginning in the mid-1980s. On a multiproduct basis, the U.S. created its first bilateral agreement with Israel in 1985, and a year earlier had created a preferential trading agreement for the Caribbean countries. But these rather minor deviations were superseded by the very significant 1987 free trade area with Canada, the United States' founding membership in APEC in 1989, the initiation of negotiations with Mexico that led to the 1993 NAFTA agreement, and ongoing negotiations for a Free Trade Area of the Americas.

On a sectoral basis, while continuing to be part of the protectionist Multifiber Arrangement, the U.S. moved to a new tack with the conclusion of "open sectoral" multilateral agreements in information technology, telecommunications, and financial services from 1996 to 1998. It is worth examining the implications of these open sectoral agreements at length. Laura Tyson, for example, has argued that among multilateral trade options, this sectoral approach is a sound alternative to the multi-sector WTO approach. ${ }^{22}$

Yet as I have argued elsewhere, open sectoralism can be politically hazardous. $^{23}$ From a political perspective, sectoral market opening is likely to reduce political support for multilateral, multisector negotiations. Because sectoral agenda setting involves a limited and easily polarized set of domestic interests, the margin for coalition building and political give-and-take is much slimmer. Moreover, industries that have succeeded in securing sectoral liberalization may pose a threat to a global liberalization agenda. These groups will see little reason to risk their existing benefits by supporting their relocation in the WTO-centered multilateral, multiproduct regime. By giving highly motivated liberal-minded interests what they sought for their specific sector, this approach contrasts sharply with the longstanding successful policy that we have seen of generally giving only temporary relief to strong protectionist interests to remove their opposition to broader liberalization. Thus, while such open sectoral liberalization seems attractive from an economic standpoint, it may actually be one step forward and two steps backward when it comes to securing freer trade.

What about the trend in U.S. policy over the last few years? President Clinton failed to obtain fast track authority during his tenure in the 1990s. Business groups continued to worry that the EU was moving forward in the negotiation of trade accords, particularly with eastward expansion. In 2001, the Business Roundtable argued:

\footnotetext{
22 Tyson 2000.

${ }^{23}$ This argument has been developed in Aggarwal 2001 and Aggarwal and Ravenhill 2001.
} 
Aggarwal: Reluctance to Lead: U.S. Trade Policy in Flux

Obviously, the best policy option is to build on the WTO framework...However, it may take regional and bilateral initiatives to jumpstart the WTO. Alternatively, we may have to undertake the regional and bilateral initiatives just to avoid discrimination by our more active trading partners. ${ }^{24}$

Once President Bush obtained fast track authority (now known as trade promotion authority), the U.S. proceeded to negotiate a large number of bilateral trade agreements often for strategic reasons with little economic rationale or direct trade benefit (Table 3 provides a snapshot of the variety of agreements that the U.S. is now pursuing, and provides a sharp contrast with the agreements that the U.S. pursued until the early 1980s.). Such prominent advocates of this approach as Fred Bergsten argued "Hence the outlook is for a series of preferential pacts over the next few years that will generate "competitive liberalization" and produce a sweeping Doha agreement by the middle of 2007."25

The US government has been explicit in closely linking foreign economic and security policy, utilizing PTAs as a reward for allies in many-but clearly not all-cases. This tendency was demonstrated in the cases of the US-Israel FTA and the US-Jordan FTA. This "securitization" of US PTA policy has further accelerated in the post-9/11 era, with many agreements focusing on countries that were willing to support the U.S. effort in the Iraq war-rather than for any obvious commercial reasons. ${ }^{26}$ Indeed until the recent accord with South Korea, still to be ratified, the total export coverage of all the agreements to this point, excluding NAFTA, was little more than $10 \% .^{27}$

What are the international implications of the pursuit of bilateral trade agreements? This so-called competitive liberalization strategy has created an important negative dynamic. As John Ravenhill notes, at the end of 2001, of 144 WTO members, only China, Hong Kong, Japan, South Korea, Mongolia, and Taiwan, had not signed a preferential trading agreement. ${ }^{28}$ This quickly changed with these members imitating the U.S. strategy of negotiating bilateral accords, and in doing so contributing to the heavily criticized "noodle bowl" in Asia. ${ }^{29}$ And with the Asians and U.S. now actively moving forward, we have now come full circle, with the EU now beginning to worry that it has been left behind in the bilateral game.

\footnotetext{
${ }^{24}$ Business Roundtable 2001.

${ }^{25}$ Bergsten 2002.

${ }^{26}$ Higgott 2004.

${ }^{27}$ Author's calculations from IMF Direction of Trade Statistics.

${ }^{28}$ Ravenhill 2003, 2.

${ }^{29}$ See Aggarwal and Urata 2006 on the proliferation of bilateral trade agreements in the AsiaPacific.
} 
Business and Politics, Vol. 11 [2009], Iss. 3, Art. 2

Table 3: U.S. Trade Policy: Mid-1980 to 2009

\begin{tabular}{|c|c|c|c|c|c|c|c|}
\hline & \multicolumn{6}{|c|}{ NUMBER OF PARTICIPANTS } \\
\hline & & \multirow{2}{*}{ Unilateral } & \multicolumn{2}{|c|}{ Bilateral } & \multicolumn{2}{|c|}{ Minilateral } & \multirow{2}{*}{ Multilateral } \\
\hline & & & $\begin{array}{l}\text { Geographically } \\
\text { Concentrated }\end{array}$ & $\begin{array}{l}\text { Geographically } \\
\text { Dispersed }\end{array}$ & $\begin{array}{l}\text { Geographically } \\
\text { Concentrated }\end{array}$ & $\begin{array}{l}\text { Geographically } \\
\text { Dispersed }\end{array}$ & \\
\hline & $\begin{array}{l}\text { Few } \\
\text { Products }\end{array}$ & $\begin{array}{l}\text { (1) } \\
\text { Super 301 } \\
(1990 \text { s) }\end{array}$ & (2) & $\begin{array}{l}\text { (3) } \\
\text { U.S.-Japan } \\
\text { VIEs (1980s- } \\
\text { 1990s) }\end{array}$ & (4) & $\begin{array}{l}\text { (5) } \\
\text { EVSL (1997) }\end{array}$ & $\begin{array}{l}\text { IT) } \\
\text { ITA (1997) } \\
\text { BTA (1998) } \\
\text { FSA (1999) }\end{array}$ \\
\hline 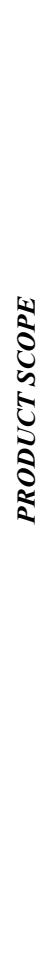 & $\begin{array}{l}\text { Many } \\
\text { Products }\end{array}$ & $\begin{array}{l}(7) \\
\text { Generalized } \\
\text { System of } \\
\text { Preferences } \\
(1976,2002) \\
\text { Andean } \\
\text { Trade } \\
\text { Preference } \\
\text { Act (1991, } \\
\text { 2002) } \\
\text { African } \\
\text { Growth and } \\
\text { Opportunity } \\
\text { Act } \\
\text { (2000) } \\
\text { Caribbean } \\
\text { Basin } \\
\text { Initiative } \\
\text { (1983, 2000) }\end{array}$ & $\begin{array}{l}(8) \\
\text { Canada-U.S. } \\
\text { FTA (1989) }\end{array}$ & $\begin{array}{l}\text { (9) } \\
\text { Israel FTA } \\
(1985) \\
\text { Jordan FTA } \\
\text { (2001) } \\
\text { Chile FTA } \\
\text { (2003) } \\
\text { Singapore FTA } \\
\text { (2003) } \\
\text { Morocco FTA } \\
\text { (2004) } \\
\text { Australia FTA } \\
\text { (2004) } \\
\text { Bahrain FTA } \\
(2006) \\
\text { Oman FTA } \\
(2006) \\
\text { Peru TPA } \\
\text { (2007) } \\
\text { Colombia FTA } \\
\text { (2006)* } \\
\text { (N) } \\
\text { Panama FTA } \\
\text { (2007)* } \\
\text { Korea FTA } \\
\text { (2007)* } \\
\text { Malaysia FTA } \\
\text { (N) } \\
\text { Thailand FTA } \\
\text { (N) }\end{array}$ & $\begin{array}{l}\text { (10) } \\
\text { NAFTA (1993) }\end{array}$ & $\begin{array}{l}(11) \\
\text { APEC (1989) } \\
\text { Dominican } \\
\text { Republic- } \\
\text { Central } \\
\text { America FTA } \\
\text { (2005) } \\
\text { Free Trade } \\
\text { Area of the } \\
\text { Americas } \\
\text { (UN) } \\
\text { South African } \\
\text { Customs Union } \\
\text { FTA (N) }\end{array}$ & $\begin{array}{l}(12) \\
\text { GATT/WTO } \\
(1947 / 1995)\end{array}$ \\
\hline
\end{tabular}

Key: An asterisk indicates that the agreement has been signed but not ratified. " $N$ " means currently being negotiated.

This focus on bilateral agreements, however, WTO plus (that is, including issues not currently covered by the WTO), could in principal have a positive effect in introducing new issues onto the WTO agenda. Indeed, looking back at the first significant U.S. bilateral trade agreements, the one with Canada that took effect in 1988, one could argue that the including new issues such as services was a positive development that helped encourage the GATT to address these concerns. Yet even strong advocates of piecemeal liberalization such as Gary Hufbauer now have second thoughts, with Hufbauer recently arguing that China

DOI: $10.2202 / 1469-3569.1257$ 
and India would "rather pursue bilateral FTAs than make the necessary concessions to push Doha across the finish line." ${ }^{30}$ Although it is impossible to perform a counterfactual experiment, one can find evidence that a narrowing of the coalition for free trade has been taking place. For example, the former head for EU trade negotiations in the WTO noted

...unlike the last global round of negotiations, when movie studios, drug companies, software makers, banks and manufacturers coalesced into a formidable free-trade lobby, the enthusiasm this time has been narrower... The lack of business lobbying has been blamed in part by Peter Mandelson, the EU trade commissioner, for the turning of the Doha Round into what he called "the Ag-only round". He said that business had failed to provide "countervailing pressure" to protectionist agricultural lobbies. ${ }^{31}$

In short, the competitive liberal approach has not led to success in the pursuit of broad scale trade liberalization, either through the DDR in the WTO or broader regional accords. Instead, bilateralism has simply fostered more bilateralism.

In addition to the active pursuit of PTAs in the George W. Bush Administration, in 2006 the U.S. shifted its position to support of a Free Trade Area of the Asia-Pacific, an idea in which it had previously shown little interest. This approach, promoted by the APEC Business Advisory Council (ABAC), an officially recognized organ created by APEC in 1995, had been an advocate for the creation of a free trade area among APEC members since 2004. Prior to Vietnam annual summit in 2006, the U.S. has show little interest in such an accord. But shortly before this summit, in a speech in Singapore, President Bush endorsed the idea of pursuing an FTAAP. This idea has found its strongest advocate in the writings of Fred Bergsten, who has argued that such an arrangement would help to control the proliferation of PTAs, prevent the development of exclusive East Asian trade arrangements, mitigate U.S.-China conflict, bolster APEC as an institution, and help to increase the prospects of concluding the DDR. ${ }^{32}$

Yet as I have argued elsewhere, these arguments are unconvincing. ${ }^{33}$ To briefly summarize, with respect to the control of PTA, as noted, only a few years ago, Bergsten argued that bilateral agreements would help to bring about a successful DDR. It is rather ironic that now an FTAAP is seen to be a useful appropriate mode of controlling what is now seen to be a pernicious development.

\footnotetext{
${ }^{30}$ The Economist, 3 September 2009.

${ }^{31}$ Financial Times, 12 December 2005.

${ }^{32}$ Bergsten 2007.

33 Aggarwal 2007.
} 
With respect to exclusive East Asian arrangements, an FTAAP promoted for this reason would appear to be a cynical U.S. strategy, and would if anything, be likely to promote such exclusive accords. On the issue of U.S-China conflict, given current domestic political dynamics in the U.S. and concern about the massive U.S. trade deficit, in the current context of the global financial crisis, an accord that promoted complete free trade China would be politically far-fetched to say the least. Given that APEC is insufficiently institutionalized, the notion that it could play a role that could foster such an accord also seems unlikely. Indeed, attempting to transform APEC into a negotiation forum, however useful as a long-term goal, would likely undermine its current contributions, however limited. Finally, piecemeal or competitive liberalization, whether in the guise of open sectoralism, bilateralism, or a transregional FTAAP are more likely to undermine the prospects for the Doha Round, as the evidence to this point would seem to indicate.

\section{The Political Economy of Trade Under the Obama Administration}

What trends do we see in U.S. trade policy under the Obama Administration? Although the fears of many that candidate Obama's discussion of renegotiating NAFTA and other protectionist statements have failed to materialize, concerns about a turn toward protectionism continue. Yet we have also seen little progress on any front - multilateral, minilateral, or bilateral - and actions to restrict tire imports in September 2009 and Mexican trucks under NAFTA in March 2009 illustrate the dangerous trend toward unilateral protectionist actions in U.S. trade policy and the increasing fragility of the pro-free trade coalition in the United States. Of course, it is worth noting that the U.S. is not alone in the pursuit of protectionist measures in the context of the financial crisis.

Turning first to the WTO's DDR, the U.S. has been working in the fall of 2009 on a bilateral basis to gain increased market access. At this point, Ron Kirk, the U.S. Trade Representative, is clearly concerned about garnering domestic support for the DDR. As he noted, "Some nations want to maintain the flexibility of telling you what they want to do later,' Mr. Kirk said. But that 'makes it more difficult for us to go to our constituents' for approval."34 He went on to say that there are 'very few people' in the U.S. Congress and the U.S. trade community that believe that the Doha round deal now on the table would create meaningful new market access." 35 With resistance for changes from its trading partners, conclusion of a meaningful DDR in the near future appears unlikely.

With respect to transregional initiatives, the Obama Administration has signaled greater interest in cooperation with ASEAN by signing the Treaty of

\footnotetext{
${ }^{34}$ New York Times, 5 September 2009, 2.

${ }^{35}$ Inside U.S. Trade, 11 September 2009.
} 
Amity and Cooperation (TAC), which some see as a forerunner to U.S. participation in the East Asia Summit, which was initiated in December 2005 by ASEAN members, South Korea, Japan, China, India, Australia, and New Zealand. $^{36}$ On FTAAP, the administration has more realistically turned to arguing that this is a long-term objective, rather than a short-term goal. The newest development with respect to the Asia Pacific is a focus on the TPP initiative. In the waning days of the Bush Administration, USTR's Susan Schwab announced that the U.S. would join TPP in September 2008. The idea was to have the U.S. and possibly other countries (Australia, Vietnam, Thailand, and Peru have expressed varying degrees of interest) "dock" their agreement to existing bilateral free trade agreement in the Asia-Pacific, in this case those among Chile, Brunei, Singapore, and New Zealand. This bottom up approach is clearly more politically feasible than a top-down negotiation involving all APEC members.

Yet even here, we have seen domestic U.S. opposition. The National Council of Textile Organizations has expressed its concern that Vietnam not be allowed to sign an agreement with the U.S. because of Vietnamese subsidies to the textile industry, and has been joined by the AFL-CIO in its opposition. ${ }^{37}$ The latter has also expressed concern about Singapore's labor laws, and the dairy and beef industries have expressed fear of New Zealand's competitive threat and the sugar industry is concerned that the TPP might lead to revision of the exclusion of sugar in the U.S.-Australia agreement. Ironically, even pro-free traders are opposed to many parts of the TPP. The most prominent of these, the Emergency Committee for American Trade, the National American of Manufacturers, and the American Farm Bureau Federation, are all concerned that a TPP might negatively impact existing PTAs that the U.S. has negotiated with Chile, Singapore, and Australia. ${ }^{38}$ In March 2009, the Obama Administration delayed its participation in TPP negotiations, arguing that it was still reviewing its trade policies - although some saw this as a sign of lack of interest by the U.S. in view of opposition by various groups.

Under the Bush Administration has made the Free Trade Area of the Americas (FTAA) a high priority for U.S. policy. Starting with the Clinton Administration (and following on the Enterprise for the Americas Initiative of President George Bush in 1990), the Summit of the Americas meeting in 1994 was seen as a way to build a hemispheric wide free trade agreement. Yet many of the same disagreements that we see in the WTO over agriculture and intellectual property beset efforts to conclude the FTAA. After the fourth summit in Mar de Plata, little has come of this approach. In September 2008, the Bush administration began to press for the Pathways to Prosperity Agreements (PPA,

\footnotetext{
${ }^{36}$ Acharya 2009.

${ }^{37}$ Fibre2Fashion, 5 March 2009.

${ }^{38}$ Inside U.S. Trade, 20 March 2009.
} 
which was seen by many as a way to salvage the FTAA). The PPA members that encompass fourteen members met in El Salvador on May 31, 2009, and President Obama has endorsed this approach of building on existing PTAs to develop a broader accord. Still, in the absence of a clear way forward, it is unclear how the PPA will evolve.

On a minilateral regional basis, although candidate Obama has called for renegotiation of NAFTA at various times in his campaign, to this point such an approach seems unlikely. On compliance with NAFTA's provisions, the U.S. has failed to comply with its commitments on trucking that were to be implemented by 2000 , both under the Bush and Obama administrations. Because Mexican trucks had been restricted to operating only within a 25 -mile zone along the U.S. border, they were forced to unload and then have American truckers take goods from that point. $^{39}$ When in March of 2009 the Obama administration cancelled the pilot program to allow Mexican truckers to move goods across the U.S., the Mexican government imposed tariffs amounting to $\$ 2.3$ billion on U.S. goods.

With respect to bilateral accords, the pursuit of such agreements has now given interest groups and their supporters a stake in their continuation. As the U.S. pursued a piecemeal approach under the Bush administration, the passage of specific accords created narrow vested interests. For example, with respect to the CAFTA debate, one source commented that the "deal drew concentrated fire from three well-organized constituencies - textile producers, sugar companies and unions. But because the CAFTA economies are so small, U.S. business didn't mount as muscular a campaign as it did in the NAFTA vote." 40 The ratification of bilateral pacts with South Korea, Panama, and Colombia remain controversial. In the Korean case, autos and beef remain contentious issues, while human rights issues beset the Panama and Colombian accords. Ron Kirk, the USTR, has repeatedly emphasized that the U.S. was not in hurry to ratify these accords, even in the face of the conclusion of an EU-Korea bilateral agreement in July $2009{ }^{41}$ In the meantime, USTR asked for public comments on the three accords. At this point, there appears to be little American appetite to pursue new PTAs, but in the absence of President Obama not having Trade Promotion Authority (TPA), the issue is currently moot in any case.

The most recent developments on a unilateral basis have increased concerns about a turn toward what some have called "murky protectionism" in the context of the financial crisis. ${ }^{42}$ This term refers to the use of measures that, although formally legal under the WTO, are discriminatory in intent. A recent

\footnotetext{
${ }^{39}$ For details, see http://www.uschamber.com/international/trade study trucking.htm, and Wall Street Journal, 2 June 2009

${ }^{40}$ Wall Street Journal, 29 July 2005.

${ }^{41}$ Reuters, 27 July 2009.

${ }^{42}$ Baldwin and Evenett 2009.
} 
Aggarwal: Reluctance to Lead: U.S. Trade Policy in Flux

study shows that in terms of protecting sectors, in the aggregate this type of protectionism in the crisis has been quite similar to the types of industries receiving protection before the crisis-despite countries claims to be using crisis as an "opportunity" to promote, for example, green technologies. ${ }^{43}$ Recent U.S. actions include restraints against chickens from China, and President Obama's controversial decision in September 2009 to impose a 35\% tariff on Chinese tires - which is technically permitted under China's WTO protocol of accession. Under this protocol, other countries had the right to restrict imports without showing any direct damage to industry, if imports began to surge. When the U.S. steelworkers union, which represents tire workers, succeeded in having the International Trade Commission (without support from industry) rule in their favor, the Obama administration had the option of rejecting the recommendation. But in light of its need to garner support from unions in his healthcare efforts, the administration imposed a three-year tariff that begins at 35\% in the first year, and then goes to $30 \%$ and then $25 \%$ in subsequent years. ${ }^{44}$ The Chinese immediately announced a study to consider retaliation against U.S. chickens and auto parts.

It is worth noting that the U.S. is hardly the only country using "murky protectionist" measures. China, for example, has blocked imports of wind turbines under 1,000 kilowatts (essentially blocking European design which are 850 kilowatts), insisted on $80 \%$ domestic content for solar power plants, and restricted exports of raw materials to help its steel industry. ${ }^{45}$ Other countries have all imposed a variety of trade restraints - their various statements in the G20 to resist protectionism to the contrary.

\section{CONCLUSION}

U.S. trade policy is currently at a standstill. In the absence of TPA, and the Doha Developmetnt Round's trouble, the U.S. is increasingly absent from trade negotiations, while others in Asia, Latin America, and Europe press forward with bilateral PTAs. Although it would have been a strategically wise move for the U.S. to call for a moratorium on such PTAs, such a move today would be seen as being totally cynical.

How did this dismal turn of events come about? In Section I of this paper I provided an analytical categorization of trade agreements as an analytical backdrop to examine U.S. trade policy in the post World War II period. I argued that traditional approaches to looking at trade arrangements have failed to adequately characterize different types of trade agreements, thereby missing the very real political and economic forces driving types of trade accords.

\footnotetext{
${ }^{43}$ Aggarwal and Evenett 2009.

${ }^{44}$ Business Week, 13 September 2009.

${ }^{45}$ New York Times, 14 July 2009.
} 
Based on this analytical effort, Section II traced how the U.S. has moved away from a traditional pursuit of multilateral multiproduct trade agreements to an increasing focus on competitive liberalization including in particular an emphasis on open sectoral and bilateral trade agreements. As I have argued, this approach has systematically undermined the coalition for free trade and diametrically opposed the previously bipartisan effort that bought off protectionist interests with an eye to promoting broad- scale trade liberalization. The result of this failed effort has been to encourage a competitive international dynamic that has delivered an increasing number of pernicious globally negotiated bilateral trade agreements - without any of the claimed beneficial effects on the negotiation of a broad-scale trade agreement that was the original raison d'etre of this misguided policy.

Currently, as noted in Section III, the domestic U.S. coalition for free trade has been undermined through the pursuit of competitive liberalization. The WTO's DDR remains mired in dispute, there has been little progress on any AsiaPacific or Latin American trade initiatives, and the bilateral route does not appear to be either promising or desirable. Instead, we have been left with the rise of "murky protectionism" with the U.S. and other countries now using legal and other mechanisms to block imports. The only promising development is that there has yet to be a dramatic turn toward protectionism in the context of the current financial crisis.

Realistically, the U.S. today has few options in providing leadership in the trading system. Yet this lack of leadership has not been replaced by any efforts on the part of other major players in the global trading system. Instead, the EU, India, China, and others have simply turned to the more active pursuit of bilateral PTAs for purely private purposes, ignoring the public good provided by trade liberalization. This sidelining of the WTO misses the important role that this institution provides in containing disputes by providing a legal mechanism to deal with such issues. Contrary to the current trend, the pursuit of bilaterals accords to simply reduce trade barriers, while useful in the short-run for business, corrodes the painfully developed institutionalized cooperation developed through the GATT and WTO. Governments and internationally oriented business, particularly in the developed countries, must pay greater attention to the construction of domestic coalitions for free trade. Ironically, in pursuing piecemeal liberalization in the name of free trade, governments, business, and their intellectual supporters have failed to see the bigger picture and understand the political economy of trade. 
Aggarwal: Reluctance to Lead: U.S. Trade Policy in Flux

\section{References}

Acharya, Amitav. 2009. The Obama Administration, Asia Pacific Security, and Canada. Asia Pacific Bulletin No. 305. Vancouver: Asia Pacific Foundation of Canada.

Aggarwal, Vinod K. 1985. Liberal Protectionism. Berkeley: University of California Press.

- 2001. Economics: International Trade. In Managing a Globalizing World: Lessons Learned, edited by P. J. Simmons and Chantal de Jonge Oudraat. Washington, D.C.: The Carnegie Endowment for International Peace.

- 2007. The Political Economy of a Free Trade Area of the Asia-Pacific: A U.S. Perspective. In An APEC Trade Agenda? The Political Economy of a Free Trade Area of the Asia-Pacific, edited by Charles Morrison and Eduardo Pedrosa. Singapore: ISEAS.

Aggarwal, Vinod K. and Simon J. Evenett. 2009. Have Long-Established Patterns of Protectionism Changed During this Crisis? A Sectoral Perspective. In Broken Promises: A G20 Summit Report by Global Trade Alert, edited by Simon J. Evenett. London: CEPR.

Aggarwal, Vinod K. and Edward Fogarty, eds. 2004. EU Trade Strategies: Between Globalism and Regionalism. London: Palgrave.

Aggarwal, Vinod K. and Kun-Chin Lin. 2002. Strategy Without Vision: The U.S. and Asia-Pacific Economic Cooperation. In APEC: The First Decade, edited by Jürgen Rüland, Eva Manske, and Werner Draguhn. London: Curzon Press.

Aggarwal, Vinod K., Robert Keohane, and David Yoffie. 1987. The Dynamics of Negotiated Protectionism. American Political Science Review 81 (2):345-66.

Aggarwal, Vinod K. and John Ravenhill. 2001. Undermining the WTO: The Case against 'Open Sectoralism'. Asia-Pacific Issues 50.

Aggarwal, Vinod K. and Shujiro Urata, eds. 2006. Bilateral Trade Arrangements in the Asia-Pacific: Origins, Evolution, and Implications. New York: Routledge.

Baldwin, Richard E. 1997. The Causes of Regionalism. World Economy 20 (7):865-88.

Baldwin, Richard E. and Simon Evenett, eds. 2009. The Collapse of Global Trade, Murky Protectionism, and the Crisis: Recommendations for the G20. VoxEU.org publication.

Bergsten, Fred. 1996. Competitive Liberalization and Global Free Trade: A Vision for the Early $21^{\text {st }}$ Century. APEC Working Papers 96 (15). Washington D.C.: Institute for International Economics.

—. 2002. A Renaissance for U.S. Trade Policy. Foreign Affairs 81 (6):86-98. 
- 2005. The Trans-Pacific Imbalance: A Disaster in the Making? Speech at the $16^{\text {th }}$ General Meeting of the Pacific Economic Cooperation Council (PECC), Seoul, 7 September.

. 2007. A Free Trade Area of the Asia-Pacific in the Wake of the Faltering Doha Round: Trade Policy Alternatives for APEC. In An APEC Trade Agenda? The Political Economy of a Free Trade Area of the Asia-Pacific, edited by Charles Morrison and Eduardo Pedrosa. Singapore: ISEAS.

Bhagwati, Jagdish. 1987. Quid Pro Quo DFI and VIEs: Political-EconomyTheoretic Analyses. International Economic Journal 1:1-14.

- 2008. Termites in the Trading System. New York: Oxford University Press.

Business Roundtable. 2001. The Case for U.S. Trade Leadership: The United States is Falling Behind. February. Available at $<$ htp://www.businessroundtable.org/publications/publication.aspx?qs=2496 BF807822B0F19D2>.

Curzon, Gerard. 1966. Multilateral Commercial Diplomacy. New York: Praeger.

Destler, I.M. 2005. American Trade Politics. Washington, D.C.: Institute for International Economics.

Diebold, William Jr. 1952. The End of the I.T.O. Princeton Essays in International Finance 16, October.

Feketekuty, Geza. 1998. An American Trade Strategy for the $21^{\text {st }}$ Century. In Trade Strategies for a New Era: Ensuring U.S. Leadership in a Global Economy, edited by Geza Feketekuty and Bruce Stokes. New York: Council on Foreign Relations.

Higgott, Richard. 2004. After Noliberal Globalization: The "Securitization" of U.S. Foreign Economic Policy in East Asia. Critical Asian Studies 36 (3):425-44.

Katzenstein, Peter J. 1997. Introduction: Asian Regionalism in Contemporary Perspective. In Network Power: Japan and Asia, edited by Peter J. Katzenstein and Takashi Shiraishi. Ithaca: Cornell University Press.

Keohane, Robert. 1990. Multilateralism: An Agenda for Research. International Journal XLV, Autumn.

Mansfield, Edward and Helen Milner. 1999. The New Wave of Regionalism. International Organization 53 (3):589-627.

Morrison, Charles and Eduardo Pedrosa, eds. 2007. An APEC Trade Agenda? The Political Economy of a Free Trade Area of the Asia-Pacific. Singapore: ISEAS.

Ravenhill, John. 2001. APEC and the Construction of Asia-Pacific Regionalism. Cambridge: Cambridge University Press.

_ 2003. The Move to Preferential Trade Agreements in the Western Pacific Rim. Asia-Pacific Issues 69. 
Richardson, David.1987. Comment. In U.S. Trade Policy in a Changing World Economy, edited by Robert Stern. Cambridge: MIT.

Schonhardt-Bailey, Cheryl, ed. 1996. Free Trade: The Repeal of the Corn Laws. Briston: Thoemmes Press.

Tyson, Laura. 2000. What Really Sabotaged the Seattle Trade Talks. Business Week, 7 February.

Yarbrough, Beth V. and Robert M. Yarbrough. 1992. Cooperation and Governance in International Trade. Princeton: Princeton University Press. 